\title{
Optimization Role of the Indonesian Navy in Economic Development Community of Coastal Areas in the West Lombok Through Islamic Perspective
}

\author{
Burhanuddin* \\ Islamic Economic and Finance, Trisakti Universit, PO box 11440, JL.Kyai Tapa No.1 Jakarta, Indonesia \\ Miyasto \\ Diponegoro University, PO box 1269, Tembalang, Kotak Pos Semarang, Indonesia \\ Tatik Mariyanti \\ Islamic Economics and Finance, Trisakti University, PO box 11440, JL.Kyai Tapa No.1 Jakarta, Indonesia \\ Hamzah \\ Bogor Agricultural University, PO box 16143, Jl. Raya Pajajaran Bogor, Indonesia
}

\begin{abstract}
The Indonesian Navy maintains national defence and security, yet supports the coastal communities' economic development. The West Lombok Regency has potential resources to support national development in better management. The Navy economic empowerment role in the West Lombok Regency is urgently needed. This study analyzes the effect of an economic empowerment program of the Navy on the welfare of coastal communities and the impact on national defence and security in sharia perspectives. It also analyzes constraint and strategic issues related the Navy's role in developing the West Lombok Regency coastal communities welfare and composes institutional models and cooperation in supporting the government to promote the coastal communities economy, producing the Navy role optimization strategies in economic empowerment of the West Lombok Regency. Quantitative and qualitative methods are used in this study, with analytical tools include the Result Impact Management System (RIMS), Descriptive Analysis, Tahwidi String Relationship, Strategic Assumption Surfacing and Testing (SAST), Interpretive Structural Modeling (ISM), and Analytic Hierarchy Process Approach (AHP). Research respondents were 150 families who were beneficiaries of CCDP-IFAD in five villages in West Lombok. The results indicate that the Navy's role in economic empowerment in the West Lombok Regency is not optimal yet. In sharia perspective, welfare affects national defence and security. To overcome this problem needs to be prepared the structured and applicable programs with field assistance. Based on the institutional model, the most desirable change issue is the establishment of real policies and legal frameworks to boost cooperation between institutions/stakeholders in empowering the coastal community and clearly institutional sharing of authority

Keywords: Economic Empowerment, Development, Coastal Community, Sharia, National Security and Resilience.

DOI: $10.7176 / \mathrm{EJBM} / 12-26-05$

Publication date:September $30^{\text {th }} 2020$

\section{Background}

The regency of the West Lombok is one of the regions in Indonesia, which has natural resources and potential maritime tourism attractions. However, there are 103.770 of the West Lombok population living in poverty based on Central Bureau Statistics of Indonesia in 2018. The Island of Lombok is situated in the coastal border areas. Indonesia, as a maritime country needs to improve the welfare of coastal communities in order to strengthen national defense and national security. The Indonesian economic potential from maritime sectors can increase threats from illegal exploitation both from abroad or local. The Indonesian Navy as one of the main components of national defense in territorial waters is obliged to maintain national sovereignty and territorial integrity of the Republic of Indonesia, maintain security stability in the territorial sea, protect natural resources in the territorial sea from various defense threats and lawlessness in territorial waters of national jurisdictions of Indonesia. The clause is sourced from the Law No. 34/2004 about Indonesian National Army (Tentara Nasional Indonesia/TNI), the Duty from Indonesian National Navy (TNI Angkatan Laut/TNI AL), in Article 9 Paragraph (e); Implementing the empowerment of the sea defense area. The support from the people in the coastal border areas is important to maintain the sustainability of the Navy's operations.

The essence of empowering sea defense areas is efforts to prepare maritime defense areas and their early supporting forces, according to the Universal Defense System (Sistem Pertahanan Semesta/Sishanta) through efforts to build, maintain, improve, and strengthen the development of maritime potential (Chief Navy Regulation No. Perasal/39 /VII/2011). In addition, this task is also implied in Chief Navy Decree Skep/847/IV/1997
\end{abstract}


concerning the Implementation of Coastal Village Development which the development of Coastal Village become State Defense and Security power in maritime which is one of the main tasks of the Navy in Non-War Military Operations (NWMO). This is the implementation of Quran Surah Ali Imran 3:200: "O you who have believed, persevere and endure and remain stationed and fear Allah that you may be successful".

This Ayah/paragraph can be a guideline for the government to maintain its state border region where Indonesia, as a maritime country, has a border area in very vast waters. Through Sishanta, the empowerment community is needed to improve their welfare. Nowadays, the war takes place in the form of modern war according to Lind (2004) referred as the fourth-generation war, in the form of asymmetrical and non-linear war relies on all infrastructure and weapons systems, political, social, economic, and cultural forces are moved comprehensively even to destroy the will to fight from the enemy with involving non-state actors, the media, psychological operations even by ignoring international agreements such as the Geneva Convention. Therefore, the government's efforts through the Navy in the economic empowerment of coastal communities are needed.

The West Lombok was chosen as the region where Coastal Community Development Project from International Fund for Agricultural Development (CCDP-IFAD) held, meaning that the potential of this region is actually good but not yet optimally utilized for development. The success of the project by other parties in line with the objectives can be used as input and evaluation of the effectiveness of the programs initiated by the Navy. The program is designed to reduce poverty and achieve sustainable economic growth in twelve coastal districts in Indonesia. This study aims to determine the effect of community empowerment programs by the government/Navy in the coastal area of West Lombok Regency to the welfare of the community is needed in determining the optimal role of the Navy.

\section{Literature Review}

\subsection{Coastal Communities Economic Empowerment Perspectives}

Coastal communities living in coastal areas and economic activities depend directly on the utilization of maritime resources. Poverty as an indicator of backwardness in coastal communities is caused by three main pillars, such as structural poverty, super structural poverty, and cultural poverty (Nikijuluw 2003). Basically, empowerment is based on the individual and social level strength. In general, Widjajanti (2011) states that the measurement of community empowerment can be seen from the empowerment consultant, the empowered community, and the empowerment process. Furthermore, Widjajanti (2011) measure the community empowerment as follows:

1. The ability of empowerment consultant is measured through three aspects of behaviour, namely: (a) knowledge/cognitive, (b) effective, and (c) psychomotor.

2. The empowerment process is measured through (a) the quality and quantity of community involvement starting from the study or problem analysis activities, (b) program planning, (c) implementing the program, and (d) involvement in ongoing evaluation.

Community empowerment is measured through three aspects (a) ability in decision making, (b) independence and (c) ability to utilize business for the future.

\subsection{Theory of Poverty}

According to Kadji (2012), the poor if it is marked by the lack or not being able to meet the level of basic human needs, namely not fulfilling primary and secondary aspects. Primary needs in the form of poor knowledge and skills, while secondary needs in the form of poor social networks, lack of financial resources, malnutrition, lack of water and housing, poor health care and relatively low education.

Rondinelli (1990) states that there are three basic program strategies that aim to help the poor population, namely the distribution of aid in areas where many poor people live, through integrated village development programs or service-oriented production projects oriented towards villagers. In addition, through assistance, it is focused on overcoming the defects of the poor people's standard of living through a program of basic human needs. Another final strategy is an aid which is centered on groups that have the same socio-economic characteristics that encourage or maintain them to continue wallowing in the circle of poverty through projects designed for certain communities.

Alfaqih (2014) states that poverty in coastal communities is rooted in the limited access to capital and a culture of entrepreneurship not conducive. The economy of the coastal community is limited to the orientation of meet the needs of daily life (Alfaqih 2014). This causes the assistance provided by the government not to be used for productive activities, but rather to meet the costs of daily needs. According to Prayetno (2013), poverty has a very large impact on the chances of a crime.

\subsection{The Role of the Navy in the Economic Empowerment of Coastal Communities}

The Indonesian National Armed Forces (Tentara Nasional Indonesia/TNI) is a defense Institution of Republic Indonesia to carry out the main tasks of upholding the country's sovereignty, maintaining territorial integrity, and protecting the national security, carrying out War Military Operation (WMO) and Non-War Military Operations 
(NWMO), and actively participating in the task of maintaining regional and international peace. The Navy as part of the TNI carries out the task of carrying out the duties of the TNI maritime force in the field of defense, enforcing the law and maintaining security in the sea territory of national jurisdiction in accordance with the rules of both national law and international law which has been ratified. In addition, the tasks of the Navy also cover economic development, Navy development, and develop community empowerment in the sea defense area. The sea, as Indonesia's strategic media, shows its existence as a maritime nation.

The development of maritime potential is an effort to carry out by the Navy through social communication, fostering territorial defense, Navy Serving, and developing maritime border areas to build the unity between Navy and People. The targets to be achieved through the development of maritime potential include the realization of a formidable effort in the form of defense areas including maritime natural resources, maritime artificial resources, and maritime infrastructure which are in every region throughout the nation, the realization of a strong effort in the form of the availability of potential maritime from human resources which have organized and trained in each region as a backup component and supporting component, and the realization of a strong effort condition which the condition of the people who have a fighting spirit, awareness of defending the nation, having a high national outlook, maintaining, preserving, and utilizing maritime resources to sustain economic prosperity and independence in order to improve the quality of life to be able to face various threats, disturbances obstacles, and challenges which come from abroad and the country.

The activity of fostering maritime area resilience is carried out by the Navy itself or with other agencies. The Navy also carries out social conditions so that people have a fighting spirit, awareness of national defense, have a high national outlook, maintain, preserve and utilize maritime resources to sustain economic prosperity and independence. The operations of the empowerment of defense territories by the Navy have a goal. First, to carry out the synergy of the strength and ability of the nation's potential in the context of the realization of the nation's defense forces at sea to carry out a universal defense system. Second, the preparation of the national potential to become a defense force prepared early covering the defense area and to supporting forces to carry out military operations for war. Third, the implementation of government programs to build, maintain, improve, and strengthen the unity between the Navy and people.

\subsection{The Theory of Welfare and Benefit of People from Sharia Perspective}

\subsubsection{Welfare}

Welfare is a condition wherein his life free from poverty, ignorance, fear, in their life, is safe and secure both physically and mentally (Adi 2012). Sunarti (2006) in her research explained in more detail and emphasized that aspects of specifications are often used as indicators to measure people's welfare are: First, Population which includes the number and rate of population growth, population distribution and density, migration and fertility. Second, Health which includes the level of public health (infant mortality, life expectancy and morbidity), the availability of health facilities, and the health status of mothers and toddlers. Third, education which includes literacy, school participation and educational facilities. Fourth, employment which includes the level of labor force participation and employment opportunities, employment and employment status, working hours and child labor. Fifth, consumption patterns and household consumption levels which include the distribution of household income and expenditure (food and non-food). Sixth, Housing and Environment, which includes the quality of the house, housing environmental facilities, and environmental cleanliness. Seventh, Socio-cultural, which includes access to obtain information and entertainment and socio-cultural activities (Sunarti 2006).

2.4.2 Welfare from an Islamic Perspective

Welfare is in the Islamic Economy, namely overall well-being, both materially and spiritually prosperous. According to P3EI (2008), the indicators of natural well-being are the fulfilment of physical needs that the need of Halal (rules that Muslim have to consume), healthy living physically and spiritually, a blessing of Rizki (benefit in Islam), families that are sure of mawaddah wa rahmah, feelings of love to others, pleasure, and qana'ah (obedient) with what God gave him and felt happy.

Welfare will be given by Allah as God in Islam if humans carry out what is ordered and stay away from what is prohibited (Syamsuddien 1994). The main goal of Islamic economics is to realize the human goal to achieve world happiness and hereafter happiness (falah), as well as a good and honorable life (al-hayah al-thayyibah). This is the definition of welfare in the Islamic view, of course, fundamentally different from the notion of welfare in conventional secular and materialistic economics (Chapra 2000).

Al-Qur'an verses/Ayah that provide an explanation of welfare some are directly/explicitly and some are indirect/implicit related to economic problems; however, the explanation using these two ways becomes one view of welfare, verses/Ayah the Qur'an includes:

1. QS (Quran Surah). Quraysh: 3-4; that the welfare indicators in the Qur'an are three, namely worshipping the God (Owner) of the Ka'aba, eliminating hunger, and eliminating fear.

2. QS. Al-Nahl: 97: welfare is a guarantee or promise from Allah given to anyone who has faith in Him, Allah will also reciprocate various good deeds of good people who are patient with rewards that are better than 
their deeds.

3. QS. Thaha: 117-119; welfare guarantees food, clothing and housing, which are termed not starving, not feeling thirsty, not being naked and not being overheated by the sun (Salim 1988).

4. QS. Al-A'raf: 10; Allah reminds His servants to give thanks for the favors He has given. The favor is a means to obtain welfare in the form of the earth which He created for a place to live, a place to fulfil all the necessities of life, to control the land, the results of its plants, its animals and its mines (Salim 1988).

5. QS. Al-Nisa: 9; welfare can be obtained only by devotion to Allah and also speaking honestly and correctly. In this verse, Allah asks His servants to pay attention to the welfare of future generations. Therefore a strong generation of devotion to Allah must be prepared.

6. QS. Al-Baqarah: 126; welfare is only obtained by surrender fully to Allah. Islamic teachings also teach about the concept of sharing, enjoying, sharing happiness and tranquillity (Salim 1988).

7. QS.At- Talaq: 2-3; A good life can be interpreted as a life that is safe, comfortable, peaceful, peaceful, spacious and free from any kinds of burdens and difficulties that it faces (Salim 1988).

Qs. Al-Hadid: 20; Al-Mawardi explained that ignorance is known as a society that often competes in terms of the luxury of worldly possessions, therefore for those who believe it is recommended to compete in terms of obedience and faith in Allah. Competing in worldly luxury can plunge humanity into the vanity of destruction, as contained in Qur'an Surah At-Takatsur verse 1-2, which means "Competition in [worldly] increase diverts you. Until you visit the graveyards." (Al-Mawardi 1982).

\section{Research Method}

The location of the study was conducted in the West Lombok Regency (The Villages are; Sekotong Barat, Buwun Mas, Cendi Manik, Lembar Selatan, and Taman Ayu). The period of study is from October 2019 to March 2020. Data to be collected in the study includes primary data and secondary data. Secondary data was collected through literature studies, internet searches, and looking for data from several institutions, such as the Indonesian Navy Headquarters, CCDP-IFAD, and the West Lombok Ministry of Maritime Affairs and Fisheries Representative Office, Central Bureau Statistics of Indonesia, Regional Governments, and other related institutions. The primary and secondary data are from the IFAD of West Lombok between 2015 and 2017 as well as data and previous research relating to community welfare. Primary data was collected using in-depth interviews with experts/informants with data/information collection instruments in the form of questionnaires that will be distributed to experts and justification/discussions with experts. In addition to direct, in-depth interview involved selected respondents and determined deliberately (purposive sampling) in accordance with their expertise and experiences.

The sample in this study were 150 households of CCDP-IFAD recipients in West Lombok Regency in five villages, namely in Sekotong Barat, Buwun Mas, Cendi Manik, Lembar Selatan, and Taman Ayu. This research uses a descriptive approach. This study uses data processing with T-Test and PCA using the Result Impact Management System (RIMS) which will describe the economic empowerment program that can improve welfare and the method of Tawhidi String Relations (TSR).

\section{Research Result}

The Coastal Community Development Program by the International Fund for Agriculture Development (CCDPIFAD) with the Ministry of Maritime Affairs and Fisheries (KKP) can be used as a lesson towards improving the performance of the Navy in the Lombok Regency. Benchmarking conducted aims to obtain information about the performance of the programs of these institutions. According to Watson (1996), benchmarking conducted by the Indonesian Navy is categorized as functional benchmarking where comparisons are made with various organizations not competitive but have similar functional activities. The Navy can learn from previous programs that have been carried out by IFAD so that it can save time and limited costs to carry out programs to optimize the role of the Navy in the development of coastal communities.

The Coastal Community Development Project (CCDP-IFAD) is only implemented in the Eastern Indonesia region, namely in the Municipality or Regency which has potential natural coastal resources, but the poverty rate of the community is more than $20 \%$ where West Lombok Regency is one of them because it has a low level of economic prosperity (Amini, Yuniati, and Salkiah 2014). The head of the West Lombok Maritime and Fisheries Department, Mr Ahmad Subandi and the West Lombok Regency Regent Mr Fauzan Khalid stated that CCDPIFAD had succeeded in impacting the West Lombok Regency both in terms of community empowerment and supporting infrastructure that succeeded in increasing people's welfare (lombokbaratkab.go.id).

In addition to facilitating infrastructure development, CCDP IFAD facilitates production input facilities for core business activities as well. Among them is the development of a fishpond center in Taman Ayu Village, the development of a processed fisheries production group and fishing facilities; like boats, engines and nets in fifteen coastal villages. CCDP-IFAD also paid attention to the tourism sector by developing new tourism, routes by building mangrove tracking pathways along with other supporting facilities as well as maintaining the tourism 
potential in West Lombok Regency that is sustainable.

Community participation in the Coastal Community Development Project (CCDP-IFAD) affects increasing income and reducing poverty (Amini and Yuliana, 2015). According to Amini, Yuniati, and Salkiah (2014) stated that the things that influence the participation of the people of West Lombok in implementing the CCDP-IFAD program are the level of education, number of families, work, and social activities. The education factor is the factor that most influences the transfer of information and technology to the community. Despite facing various obstacles, especially related to the receipt of information due to educational factors, the presence of assistance and periodic evaluations can help the program work well.

The evidence of the success of CCDP-IFAD in West Lombok Regency can be seen from the Asset Index (relative poverty/wealth). Variables that are the basis in the measurement of poverty asset index include the type of floor of the house, the source of drinking water, sanitation facilities (the type of toilet), electricity, ownership of assets, fuel for cooking, and the density of the bedroom (density/number of family members/number Bedroom). The measurement was carried out through comparisons of the period of 2013, 2015, to 2017. The use of water sources through pipes increased by $22 \%$ while the use of draw wells decreased by $37 \%$. The people of West Lombok are also beginning to realize the importance of sanitation, where the use of open latrines has decreased by more than $50 \%$.

In terms of fuel, the use of firewood is shifting to the use of electricity which is more dominant where the increased electricity usage is also accompanied by the need for entertainment for the use of mobile phones, televisions, and motor vehicles that use fuel. The increase in electricity demand was also accompanied by an increase in the need for community boards as seen from the use of ceramics which increased by $23 \%$ while the use of other floors (bamboo, wood, cement, land) decreased. The livelihoods of coastal communities have also experienced a change in trends where the ownership of livestock has increased, but the area of conversion of agricultural land to non-agriculture has also increased. However, these changes are also accompanied by increasingly sophisticated farming tools, for example with more tractor usage compared to traditional tools and the use of coolers for storage of agricultural products.

The impact of the CCDP-IFAD on the business economy, for example, in the capture fisheries sector, business assets of ownership of vessels changed from small motorized vessels to larger-sized vessels that increased by $100 \%$. While the fishing gear used is also increasingly varied and more considerate the sustainability of natural resources. In aquaculture, the people of West Lombok also showed an increase in business assets. Where the area of cultivation increased by more than $50 \%$ and the use of generators or the need for electricity increased rapidly. The survey results from 2015 to 2017 show that the average production of fish ponds last month increased by an average of $153.9 \%$, but shrimp farming and the like must actually be stopped in 2017 due to various factors including disease outbreaks and pollution. However, shrimp and lobster cultivation are very promising. This is proven by the still rampant smuggling of baby lobsters originating from West Lombok which was foiled by the Indonesian Navy through the port of Lembar.

The success of CCDP-IFAD, it can be seen in the MSME sector, is the number of processed fishery products that are increasingly varied. In 2015, products that were generally produced were limited to fish chips and grilled fish. But in 2017 there are a variety of more complex fish preparations such as fish balls. The product is also supported by improvements in packaging and acquisition of permits in stages so that in the end, the product can be widely marketed. Total annual production increases by up to $200 \%$. An increase in this sector can provide fresh air for jobs available in West Lombok Regency so as to improve the community's welfare.

In the tourism sector, construction of tourism support infrastructure is needed to attract tourists. When the project was completed in 2017 , the government, together with the community, are committed to maintaining community motivation and the results of the project to be carried out independently by the community. According to Rahmawati and Nizar (2019), the community stated that the existence of mangrove ecotourism that developed in West Lombok, had an impact on improving the economy for the community such as employment, increased income, infrastructure, and catch productivity. Mangrove critical land owned by West Lombok continues to be utilized as a mainstay in the tourism sector. After the CCDP-IFAD project ended in 2017, the community together continued to develop ecotourism by utilizing the village funds owned and continuing to improve the management of mangrove ecotourism tourism. That is, the community itself felt the real impact of the program.

If seen from the valuation of assets owned by the people of West Lombok, the total value of assets owned by the public in 2017 is valued at more than ten million rupiah over 35\% while others are in the middle category. The total annual turnover obtained also experienced a significant change where the people of West Lombok who have an annual turnover of more than ten million rupiah reached $50 \%$. This is due to the number of households who understand the planning and management of fisheries and maritime resources increased from $6.30 \%$ to $63.50 \%$.

Overall, the indicators in the PCA analysis are the poverty rate, the number of female as single-family, malnutrition, and food security. The food security rate in West Lombok also experienced an increase where from 2015 to 2017 the famine season or food shortages in West Lombok reach to $0 \%$. The food security is explained in Table 1. 
Table 1. Duration of Famine Season

\begin{tabular}{|l|r|r|r|r|r|r|}
\hline \multirow{4}{*}{ Duration } & \multicolumn{2}{|c|}{2013} & \multicolumn{2}{c|}{$\mathbf{2 0 1 5}$} & \multicolumn{2}{c|}{$\mathbf{2 0 1 7}$} \\
\cline { 2 - 7 } & Season 1 & Season 2 & Season 1 & \multicolumn{1}{c|}{ Season 2 } & \multicolumn{1}{c|}{ Season 1 } & Season 2 \\
\cline { 2 - 7 } & Sub-Total & Sub-Total & Sub-Total & Sub-Total & Sub-Total & Sub-Total \\
\hline Famine & 116 & 28 & 15 & 1 & 21 & 0 \\
\hline Not in Famine & 24 & 122 & 135 & 149 & 129 & 150 \\
\hline Total & 150 & 150 & 150 & 150 & 150 & 150 \\
\hline
\end{tabular}

In addition to food security, child nutrition is also an indicator. Nutritional status assessment is carried out using anthropometry and following World Health Organization (WHO) standards. This measurement is presented in the form of an index that is associated with other variables, namely, age, weight, and height. There are three indicators of malnutrition used, namely: (i) chronic nutritional conditions in toddlers (stunting) by measuring the height to age; (ii) acute nutritional conditions (wasting) by measuring body weight for height; and (iii) underweight nutrition.

The number of toddlers (children under five years old) analyzed based on the standard WHO Z-score in the malnutrition category is less than the baseline in 2013 and 2015. In the 2017 RIMS survey, the number of toddlers experiencing malnutrition problems fell by 96 people. Thus a decrease in the number of children under five, including malnutrition. Quantitatively, the number of children under five is categorized as acute malnutrition, chronic malnutrition, and underweight babies in the 2017 RIMS survey compared to the 2013 and 2015 baselines appear to have decreased significantly. The results of this survey show a decrease in the number of children under five suffering from malnutrition after the CCDP-IFAD program (Table 2).

Table 2. Nutrirional Status of Children Under 5 Years

\begin{tabular}{|c|c|c|c|c|c|c|c|c|c|c|c|c|c|}
\hline \multicolumn{14}{|c|}{ Survey Result at 2013} \\
\hline \multirow{3}{*}{ Gender } & \multirow{3}{*}{$\begin{array}{c}\text { Total } \\
\text { Respondent }\end{array}$} & \multicolumn{4}{|c|}{$\begin{array}{c}\text { The child with Acute } \\
\text { Malnutrition } \\
\text { (Weight \& Height) }\end{array}$} & \multicolumn{4}{|c|}{$\begin{array}{c}\text { The child with Chronic } \\
\text { Malnutrition } \\
\text { (Weight \& Height) }\end{array}$} & \multicolumn{4}{|c|}{$\begin{array}{c}\text { Thin Child } \\
\text { (Weight \& Height) }\end{array}$} \\
\hline & & \multicolumn{2}{|c|}{$\begin{array}{l}\text { Above } 2 \text { Z- } \\
\text { Score }\end{array}$} & \multicolumn{2}{|c|}{$\begin{array}{l}\text { Below } 2 \text { Z- } \\
\text { Score }\end{array}$} & \multicolumn{2}{|c|}{$\begin{array}{l}\text { Above } 2 \text { Z- } \\
\text { Score }\end{array}$} & \multicolumn{2}{|c|}{$\begin{array}{l}\text { Below } 2 \text { Z- } \\
\text { Score }\end{array}$} & \multicolumn{2}{|c|}{$\begin{array}{l}\text { Above } 2 \text { Z- } \\
\text { Score }\end{array}$} & \multicolumn{2}{|c|}{$\begin{array}{l}\text { Below } 2 \text { Z- } \\
\text { Score }\end{array}$} \\
\hline & & Total & $\%$ & Total & $\%$ & Total & $\%$ & Total & $\%$ & Total & $\%$ & Total & $\%$ \\
\hline Total & 123 & 117 & 95,0 & 6 & 6.0 & 76 & 69,0 & 47 & 38,0 & 102 & 83,0 & 21 & 17,0 \\
\hline \multicolumn{2}{|c|}{$\begin{array}{l}\text { Confidence Interval } \\
95 \%\end{array}$} & \multicolumn{2}{|c|}{5,31} & \multicolumn{2}{|c|}{4,45} & \multicolumn{2}{|c|}{39,18} & \multicolumn{2}{|c|}{37,24} & \multicolumn{2}{|c|}{17,83} & \multicolumn{2}{|c|}{16,32} \\
\hline \multicolumn{14}{|c|}{ Survey Result at 2015} \\
\hline \multirow{3}{*}{ Gender } & \multirow{3}{*}{$\begin{array}{c}\text { Total } \\
\text { Respondent }\end{array}$} & \multicolumn{4}{|c|}{$\begin{array}{l}\text { The child with Acute } \\
\text { Malnutrition } \\
\text { (Weight \& Height) }\end{array}$} & \multicolumn{4}{|c|}{$\begin{array}{c}\text { The child with Chronic } \\
\text { Malnutrition } \\
\text { (Weight \& Height) }\end{array}$} & \multicolumn{4}{|c|}{$\begin{array}{c}\text { Thin Child } \\
\text { (Weight \& Height) }\end{array}$} \\
\hline & & \multicolumn{2}{|c|}{$\begin{array}{l}\text { Above } 2 \text { Z- } \\
\text { Score }\end{array}$} & \multicolumn{2}{|c|}{$\begin{array}{l}\text { Below } 2 \text { Z- } \\
\text { Score }\end{array}$} & \multicolumn{2}{|c|}{$\begin{array}{l}\text { Above } 2 \text { Z- } \\
\text { Score }\end{array}$} & \multicolumn{2}{|c|}{$\begin{array}{l}\text { Below } 2 \text { Z- } \\
\text { Score }\end{array}$} & \multicolumn{2}{|c|}{$\begin{array}{l}\text { Above } 2 \text { Z- } \\
\text { Score }\end{array}$} & \multicolumn{2}{|c|}{$\begin{array}{l}\text { Below } 2 \text { Z- } \\
\text { Score }\end{array}$} \\
\hline & & Total & $\%$ & Total & $\%$ & Total & $\%$ & Total & $\%$ & Total & $\%$ & Total & $\%$ \\
\hline Total & 21 & 19 & 90,0 & 2 & 18,0 & 12 & 57,0 & 9 & 43,0 & 18 & 86,0 & 3 & 14,0 \\
\hline \multicolumn{2}{|c|}{$\begin{array}{l}\text { Confidence } \\
95 \%\end{array}$} & \multicolumn{2}{|c|}{19,69} & 18 , & & 35 , & & 33 , & & 21, & & 20 , & \\
\hline & & & & & Irvey & sult at & 2017 & & & & & & \\
\hline & Total & & $\begin{array}{l}\text { child } \\
\text { Maln } \\
\text { eight }\end{array}$ & $\begin{array}{l}\text { vith Act } \\
\text { rition } \\
\text { Heigh }\end{array}$ & & The & $\begin{array}{l}\text { child v } \\
\text { Malnt } \\
\text { eight }\end{array}$ & $\begin{array}{l}\text { th Chr } \\
\text { rition } \\
\text { Heigh }\end{array}$ & & & $\begin{array}{l}\text { Thi } \\
\text { eigh }\end{array}$ & $\begin{array}{l}\text { hild } \\
\text { Heigh }\end{array}$ & \\
\hline Gender & Respondent & $\begin{array}{r}\text { Abov } \\
\text { Sce }\end{array}$ & $\begin{array}{l}2 \mathrm{Z}- \\
\mathrm{re}\end{array}$ & $\begin{array}{r}\text { Below } \\
\text { Sco }\end{array}$ & $2 \mathrm{Z-}$ & $\begin{array}{r}\text { Above } \\
\text { Sco }\end{array}$ & $\begin{array}{ll}2 \mathrm{Z}- \\
\mathrm{re}\end{array}$ & $\begin{array}{r}\text { Belon } \\
\text { Sec }\end{array}$ & $\begin{array}{l}2 \mathrm{Z}- \\
\mathrm{re}\end{array}$ & $\begin{array}{r}\text { Above } \\
\text { Sco } \\
\end{array}$ & $2 \mathrm{Z}-$ & $\begin{array}{r}\text { Belon } \\
\text { Sec }\end{array}$ & $2 \mathrm{Z}-$ \\
\hline & & Total & $\%$ & Total & $\%$ & Total & $\%$ & Total & $\%$ & Total & $\%$ & Total & $\%$ \\
\hline Total & 27 & 22 & 81,0 & 5 & 19,0 & 12 & 44,0 & 15 & 56,0 & 18 & 67,0 & 9 & 33,0 \\
\hline $\begin{array}{l}\text { Confiden } \\
95 \%\end{array}$ & Interval & 19 & & 17 , & & 51 , & & 49 , & & 37 , & & 35 , & \\
\hline
\end{tabular}

Note: Calculation is done using WHO growth standards, Second set.

Source: Maritime Affairs and Fisheries Office West Lombok 2017, data processed

Meanwhile, the level of welfare of the people of the West Lombok based on indicators or previous factors can be concluded with people who are categorized as very poor, having decreased from $23 \%$ to $10.1 \%$. In contrast, those in the very rich category reached $40 \%$. People in the poor category have decreased, and people in the rich category have increased. Communities with an average economic situation experienced an increase in 2015, which then declined in 2017. These statistics can be seen in Figure 1. 


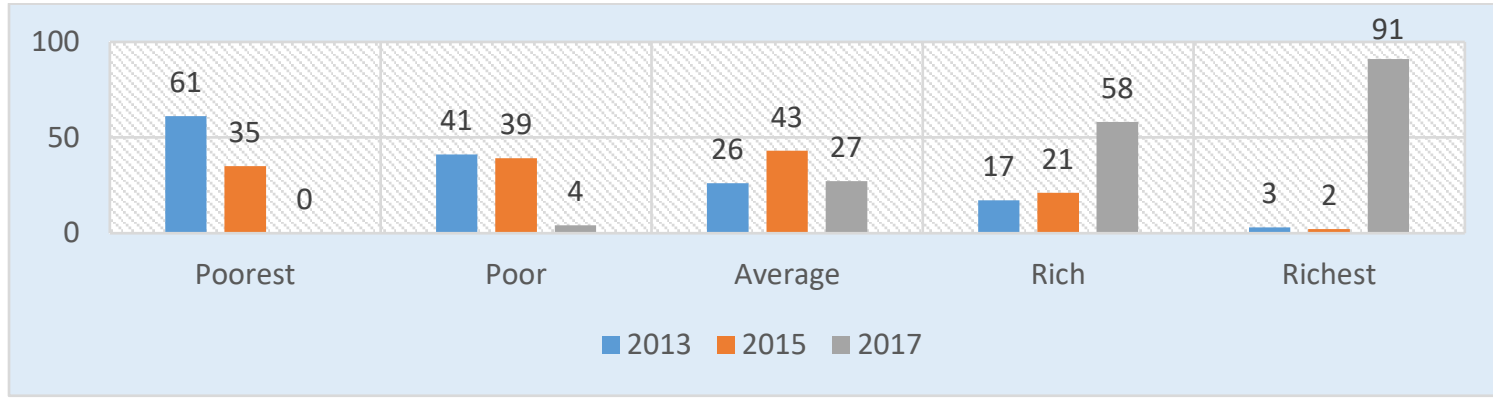

Figure 1. Asset Ownership Index

Source: Maritime Affairs and Fisheries Office West Lombok (2020) is processed

Meanwhile, in the socio-economic indicators, it can be seen that there is a percentage change in households headed by women were in 2017 , the figure reached $3 \%$. When viewed based on literacy skills, it can be shown that the percentage of female and male family members who can read increases, although not rapidly. In addition, in 2017, the people of West Lombok have begun to realize the importance of sanitation in clean water by showing an increasing number of households with safer sanitation. In detail, socio-economic indicators can be seen in Table 3.

Table 3. Social Economic Indicator of Lombok Barat Community

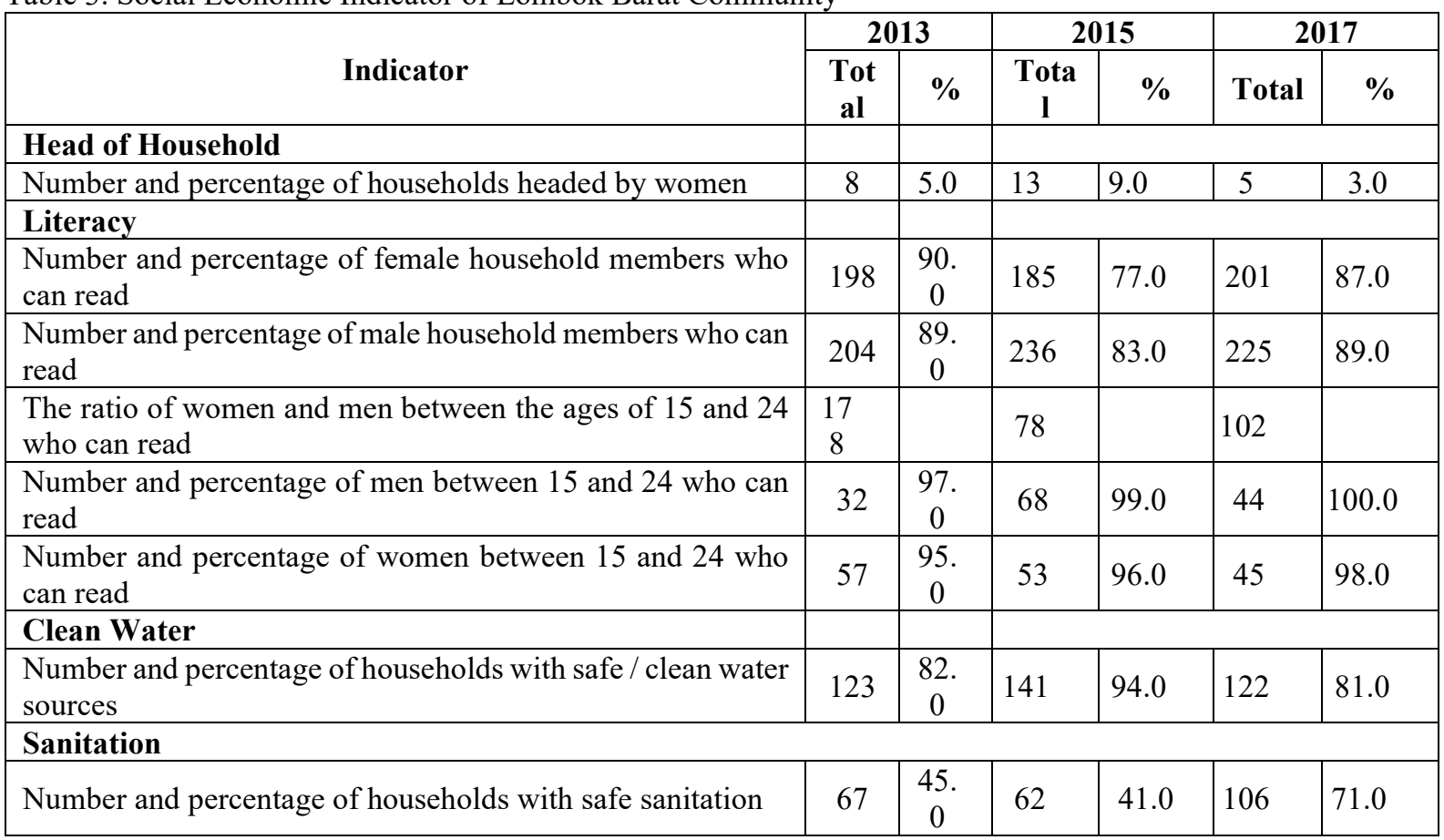

Source: Maritime Affairs and Fisheries Office West Lombok 2020, data is processed

The success of the CCDP-IFAD in collaboration with the government and stakeholders realize the achievement of the objectives of the program. Although the program ended in 2017, the psychological impact on the community is still felt where these programs can stimulate other programs both independently and in collaboration with the government. The Indonesian Navy, which has the task of empowering coastal communities, needs to make it as a benchmark for the programs carried out by IFAD and the government.

The Navy's (Bina Desa Pesisir/Bindesir-Coastal Village Empowerment) aims to ensure that coastal villages which are designated as target villages that are still relatively underdeveloped, socio-economic conditions can be mobilized and empowered to be able to increase their role in regional economic development, which in turn can improve people's welfare. Marine Base in Mataram as the Navy ranks in West Lombok Regency has carried out various activities which can help the community. One of them was during the earthquake in Lombok, West Nusa Tenggara (NTB), the Indonesian Navy deployed elements of the KRI (Kapal Republik Indonesia/Indonesian Warship) as the support for the national disaster. On that occasion, the Indonesian Navy also deployed 200 Marine Corps troops who were members of the Maritime Disaster Management Task Force. Then forty transport trucks from various Indonesian Navy units for the distribution of aid to disaster locations in Lombok, the Indonesian Navy escort unit, the involvement of security personnel both open and closed security in order to maintain the security of the aid material, to the involvement of the health team. At almost the same time, the Kolinlamil 
(Command of Military Sea Traffic) mobilized its warship elements to support the departure of the TNI Task Force and transport aid to the victims of the Lombok earthquake. In addition, assistance after the earthquake occurred such as repairs of public facilities such as Rinjani climbing routes, residents' homes, and public facilities and infrastructure, also assisted by the Navy together with the community.

The Indonesian Navy also provided social, health, economic and educational assistance. Among them is the construction of a marine monument to be a tourist attraction. The Indonesian Navy has also formed the "Saka Bahari" to be a seed in increasing the knowledge and practical skills in the field of maritime life that are useful for self, family, and the environment then it can create provisions in developing employment. In addition, the Indonesian Navy in economic activities also helped the community through cooperation with Bank Indonesia by providing mobile cash to maintain the value of the rupiah and increase economic growth. Other cooperation established by the Navy with Pelindo was also carried out to develop the Sheet port in 2016 as an important asset driving the economy of the West Lombok Regency. The Indonesian Navy has also assisted the efforts to conserve local mangroves as an effort to sustainably manage natural resources and increase the attractiveness of the tourism sector in the West Lombok Regency. Based on the Navy coastal community empowerment guidebook, the community development strategy adopted by the Navy has similarities to CCDP-IFAD (2017), namely through the bottom-up where assistance is given based on the community's potential and needs. However, the role of the Navy still seems not optimal. The opinion of respondents indicates this with the proportion of the Navy's role in economic empowerment that agrees and strongly agrees to have an average proportion of less than $50 \%$ and a lack of synergy with the local government and stakeholders. Each agency involves sectoral ego in empowering coastal communities. The programs provided have not been intensive in explicit economic activity. Even though the Navy has the ability and authority, it can be used properly in the economic empowerment of coastal communities. The Indonesian Navy, which is supposed to play an important role in economic activities in order to guarantee increased welfare, so as to increase defense and security, is still very limited in its movements due to budgetary constraints other than the issue of synergy.

\subsection{Islamic Economics from the People of the West Lombok Coastal Region}

The results of the study stated that the Islamic economy has been going well in the area of the West Lombok Regency which is seen by the opinions of experts strongly agree at $53.3 \%$ and those who disagree only at $6.7 \%$. The Marine Base of Mataram indicator gives the spirit of nationalism into the Islamic Economic run by the community showing that of $73.4 \%$ the experts agreed and strongly agreed. On the economic empowerment, program indicators do not conflict with Islamic economics shows that $66.7 \%$ of respondents agree and strongly agree. On indicators, there need to be further and creative breakthroughs so that the program can encourage the progress of the Islamic economy, indicating that $73.4 \%$ of experts agree and strongly agree. The Navy should work closely with Islamic economic institutions and benefit the coastal communities $66.7 \%$ of experts agree and strongly agree. The Maritime Community Empowerment program indicator is still not consistent showing 53.3\% of experts answered neutrally. From the results of the analysis, Islamic Economic variables by the people of the coastal region in West Lombok have been going well. Thus it can be concluded that the program provided by the Navy is fully capable of developing the Islamic economy from the people of the coastal areas of West Lombok.

\subsection{Relationship of Coastal Community Welfare with National Defense and Security}

Synergistic implementation of the national defense system is needed to have a real impact. Indonesia, as a maritime country, has a high level of vulnerability to threats because of its maritime potency. Efforts to safeguard the sovereignty of the Indonesian state are by implementing a defense system that involves all components of the nation (Yanti 2014), which is carried out in various non-military ways through various sectors.

Nasution (2009) states defending the country can describe national resilience. Efforts to defend the country are obtained through welfare and security that affect national resilience. Coastal community empowerment can influence the defense of the country so that the emergence of a high sense of ownership and the quality of human resources is sufficient to carry out the defense of the country (Nasution 2009). Coastal community empowerment indirectly affects national security by improving the welfare of local communities (Sadarianto, Anwar, and Purwanto 2018). Regional development from economic, social and cultural aspects significantly influences national defense (Nasution 2009). The simultaneous implication, good national security and security stability can also affect the state of the economy and the welfare of the country from various fields as a whole (Taufiq 2013).

This is also in line with one of the main tasks of the Indonesian National Defense Force (TNI) which is written in the article 7 paragraph 2 number 8 of the Republic of Indonesia Law No. 34/2004 about the TNI, that in NonWar Military Operations must carry out empowerment of the people as supporting forces in the regional defense. Human resources, capital, and nature that are managed well in a sustainable manner will assist the government in maintaining national security and security. 
4.3 Welfare, Security, and National Security in Sharia Pespective

Islam defines welfare, including the material and non-material aspects. Islam teaches that wealth is not the only indicator of welfare because basically, assets are only medium to worship Allah. This is explained by Allah in the Qur'an Surah Adz-Zariyat verses 56-58.

Coastal communities can work together with the Navy in working at sea to achieve prosperity. However, the Navy, in carrying out its duties, is always faced with various kinds of obstacles. The obstacle faced include the confusion of authority among agencies which help maintain maritime security and the lack of equipment owned by the Navy. The solution of this obstacle is the need for the establishment of clear statutory regulation in dividing authority between agencies to protect the sea area. In addition, it is necessary to establish a substitute agency which has complete authority to maintain the security of the territorial waters of the Republic of Indonesia. The God has also called on His people to always guard their border areas based on the Qur'an Surah Ali Imran: 200 and Qur'an Surah An-Nahl: 14 shows that Muslims are prescribed to use the sea reach prosperity. The implementation of God's order based on Qur'an Surah An-Nahl: 14 is in accordance with the Navy's duty based on the mandate of the law to participate in maritime management to maintain national security. The welfare of coastal communities which must be realized through the role of the Navy must include the following Maqashid Sharia: (1) Ad-dien: Preserving the Religion, (2) An-nafs: Preserving the Soul, (3) Al-aql: Preserving the Mind, (4) An-nasl: Preserving the Descendants, (5) Al-maal: Preserving the Assets.

The state thus must use power and authority to realize justice and prevent tyranny, such as the occurrence of illegal fishing at sea, the Navy must take preventative measures to uphold justice for the realization of the welfare of coastal communities. In addition, in the opinion from Dr Abdul Sattar in the holy book Al-Muamalah Fil Islam, the meaning of the above verse is as follows: (1) the main purpose of risalah ilahiyah (in the book and shari'ah) is that the state is obliged to enforce a rule (nizham) in muamalah among humans. (2) The state is obliged to enforce a justice sharia rule (power/strength), after preaching and tabligh/communication. This has been carried out by the Islamic leaders of the Islamic first period. The rulers were very aware of their responsibilities as head of state towards the economy of the community, especially towards meeting the basic needs of all citizens. Based on the previous description shows that the role of the Navy to realize the welfare of sharia-based coastal communities is through its role as an extension of the government so that in carrying out its duties the Navy can enforce justice with power and authorities.

\section{Conclusion}

Based on the results of the study it can be concluded that the community empowerment program by the Navy as government representative in the coastal areas towards community welfare, specifically in the West Lombok in the form of Community Empowerment Program (Bindesir) has not been optimally felt by the community. The role is not optimal due to the lack of synergy among stakeholders, among the central government, local government, and the Navy. Previously, in the West Lombok Regency, there was a recipient of CCDP-IFAD program which was considered successful in improving the welfare of the local community so that it could be used as a benchmark. However, the Indonesian Navy has not been able to photograph clearly the example of the program. In comparison, prosperity influences national security both in a general perspective and sharia perspective.

\section{References}

Adi, I.R. (2012). Increasing Family Capacity as a Potential and Source of Social Welfare. - in Bahasa Indonesia.

Alfaqih, I. (2014). Implementation of Community Direct Assistance in the National Community Empowerment Program (PNPM)-Independent in Sapeken Village, Sapeken District, Sumenep Regency. Surabaya (ID): Universitas Pembangunan Nasional "Veteran" Jatim, Faculty of Social and Political Science. - in Bahasa Indonesia.

Al-Mawardi, A. (1982). An-Nukat Wa Al-Uyun Tafsir al-Mawardi.Vol.4. Kuwait: Wizarat al-Auqaf Wa as-Syu'un al-Islamiyah.

Amini, R, Yuliana, B. (2015). Analysis of the Effect of Community Participation in Coastal Community Development Projects (CCDP-IFAD) on Poverty in West Lombok District. Universitas Nahdlatul Wathan Mataram. Ganeç Swara Vol. 9 No.1. - in Bahasa Indonesia.

Amini, R, Yuniati, M, dan Salkiah, B. (2014). Analysis of Factors Affecting Community Participation in Coastal Community Development Projects (Ccdp-Ifad) in West Lombok Regency. Jurnal Ganec Swara, 8. Lombok (ID): Universitas Nahdlatul Wathan Mataram. - in Bahasa Indonesia.

Central Bureau Statistic of West Lombok. (2018). West Lombok Regency Economic Growth Rate (percent) in 2015-2018. West Lombok: Central Bureau Statistic. https://lombokbaratkab.bps.go.id/.

Chapra, M.U. (2000). Islam and Economic Challenges. Jakarta (ID): Gema Insani Press. - in Bahasa Indonesia.

Kadji, Y. (2012). Poverty and its theoretical concepts. Professor of Public Policy Faculty of Economic and Business UNG. - in Bahasa Indonesia.

Lind, W. (2004). Understanding Fourth Generation War, Military Review September-October. https:// 
www.au.af.mil/au/awc/awcgate/ milreview/lind.pdf.

Lombokbaratkab.go.id. (2016). http://lombokbaratkab.go.id/keberhasilan-ccdp-ifad-mengubah-wajahmasyarakat-pesisir-lombok-barar/. By Anwar ST/ Agustus 23rd, 2016. Warta Media "Keberhasilan CCDP IFAD Mengubah Wajah Masyarakat Pesisir Lombok Barat”.

Nasution, A. (2009). The Effect of Regional Development (Social and Cultural Economic Aspects) on National Defense in the East Coast Region of North Sumatra. Wahana hijau Vol. 4 No. 3. Kapendam Kodam I Bukit Barisan. Medan (ID): Universitas Sumatera Utara. - in Bahasa Indonesia.

Nikijuluw, V.P.H. (2003). Socio-Economic Aspects of Coastal Communities and Empowerment Strategies in the context of Integrated Management of Coastal Resources. USAID-Indonesia Coastal Resources Management Project.

Prayetno, P. (2013). Causality of Poverty against Criminal Acts (Theft). Media Komunikasi FIS, 12(1). Medan (ID): Universitas Negeri Medan. - in Bahasa Indonesia.

Rahmawati, Nizar WY. (2019). Efforts to Preserve and Develop Mangrove Tracking Ecotourism in Lembar Selatan Village, lembar District, West Lombok. Jurnal Silva Samalas Volume 2, No. 1. Mataram (ID): Fakultas Ilmu Kehutanan Universitas Nusa Tenggara Barat. - in Bahasa Indonesia.

Rondinelli, D.A. (1990). Housing the Urban Poor in Developing Countries: The Magnitude of Housing Deficiencies and the Failure of Conventional Strategies are World-wide Problems. American Journal of Economics and Sociology, 49(2), 153-166.

Sadarianto, Anwar, S, Purwanto. (2018). The Effect of Empowerment of Maritime Areas and Fishermen Training on Coastal Community Welfare in Order to Optimize Defense Strategies in Gisik Cemandi Village, Sidoarjo Regency. Jurnal Prode Strategi Perang Semesta Vol. 4 No 3. Universitas Pertahanan. - in Bahasa Indonesia.

Sunarti, E. (2006). Prosperous Family Indicators: History of Development, Evaluation and Sustainability. Bogor (ID): Fakultas Ekologi Manusia, Institut Pertanian Bogor. - in Bahasa Indonesia.

Syamsuddien, D.I.D. (1994). Prototype of a Country of Peace. Surabaya (ID): Media Idaman Press. - in Bahasa Indonesia.

Taufiq, M. (2013). Increased Prevention of Radicalism for Internal Security Stability within the Framework of National Resilience. Lembaga Ketahanan Nasional Republic of Indonesia. - in Bahasa Indonesia.

Watson, G.H. (1996). Strategic Benchmarking. Jakarta(ID): Gramedia Pustaka Utama. - in Bahasa Indonesia.

Widjajanti, K. (2011). Community Empowerment Model. Jurnal Ekonomi Pembangunan Volume 12, Nomor 1, Juni 2011, hlm.15-27. Semarang (ID): Fakultas Ekonomi Universitas Semarang. - in Bahasa Indonesia.

Yanti, B.V.I. (2014). Fishermen Capacity Building Related to National Defense Efforts in Border Areas. Jurnal Kebijakan Sosek KP Vol. 4 No. 1. - in Bahasa Indonesia. 